XXVII Congresssa de Iniciaçẫo Cientifíica Unicamp

16 a 18 de outubro de 2019 - Campinas | Brasil

\title{
VOGUE NO BRASIL: PRIMEIROS PASSOS
}

\author{
Diego de Carvalho Silva*, Profa. Dra. Paula Teixeira Fernandes
}

\section{Resumo}

O Vogue é uma cultura que também originou uma modalidade de dança. Provém das minorias LGBTQ+ (Lésbicas, Gays, Bissexuais, Transgêneros e Queer), latinas e afrodescendentes, e proporciona empoderamento e liberdade de expressão. Após ser difundida com a ajuda de Madonna e um documentário de sucesso, o mundo conheceu o Vogue, e a cultura não parou de crescer. O objetivo deste trabalho então foi caracterizar os primeiros praticantes de Vogue, norteamericanos, e os praticantes brasileiros e estabelecer comparação entre os perfis e as motivações para o contato e a prática. Este estudo contou com 90 voluntários, que responderam a um questionário de 20 perguntas sobre o Vogue. A análise dos resultados concluiu que os brasileiros possuem conhecimento superficial e motivações tanto semelhantes quanto distintas aos pioneiros. Este trabalho serve como fonte de conhecimento histórico sobre o nascimento e a trajetória de uma cultura que nasceu em um país, porém renasceu em muitos outros.

Palavras-chave: Vogue, motivação, Psicologia do Esporte.

\section{Introdução}

O Vogue vem de Nova Iorque e é uma cultura que também originou uma modalidade de dança. Provém das minorias LGBTQ+ (Lésbicas, Gays, Bissexuais, Transgêneros e Queer), afrodescendentes e latinas, e proporciona empoderamento e liberdade de expressão.

\section{Objetivo}

Caracterizar os primeiros praticantes de Vogue, norteamericanos, e os praticantes brasileiros, e estabelecer comparação entre os perfis e as motivações para o contato e a prática da modalidade.

\section{Métodos}

\section{Participantes:}

- 90 praticantes de Vogue, $70 \%$ do sexo masculino.

- Idade média de 22,7 (DP=8,84).

Instrumento:

- Questionário online e anônimo (Google Forms).

\section{Resultados}

Tabela 1. Conhecimento sobre Vogue: participantes brasileiros.

\begin{tabular}{|c|c|c|}
\hline PERGUNTAS & RESPOSTAS & $\%(\mathbf{N})$ \\
$\begin{array}{c}\text { Conhece a música } \\
\text { "Vogue", de } \\
\text { Madonna, e seu } \\
\text { videoclipe }\end{array}$ & Sim & $96,7 \%(87)$ \\
Já assistiu ao & Não & $3,3 \%(3)$ \\
documentário "Paris & & \\
is Burning", de 1991 & Sim & $90 \%(81)$ \\
Sabe dizer onde & Não & $10 \%(9)$ \\
nasceu o Vogue & Sim & $93,3 \%(84)$ \\
Sabe o motivo de se & Não & $6,7 \%(6)$ \\
chamar Vogue & Sim & $87,8 \%(79)$ \\
Sabe o que são & Não & $12,2 \%(11)$ \\
Balls & Sim & $98,9 \%(89)$ \\
Já foi em uma Ball & Não & $1,1 \%(1)$ \\
& Sim & $86,7 \%(78)$ \\
\hline
\end{tabular}
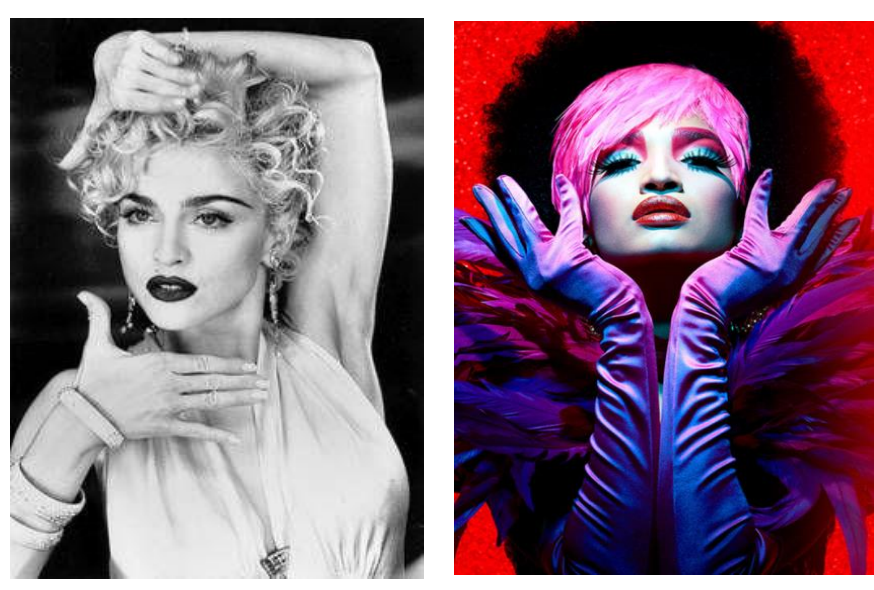

\section{Discussão}

Majoritariamente motivados pela liberdade de expressão e representatividade LGBTQ+, 90\% dos praticantes brasileiros entrevistados já praticava outra modalidade antes do Vogue e realizam a prática, tanto em aspectos profissionais e de estudo, quanto para lazer. Diferentemente dos norteamericanos, que apresentaram as balls e os treinos informais como fonte de conhecimento, a internet foi apontada como maior fonte de acesso à informações, estudos e referências.

\section{Conclusões}

Os praticantes brasileiros possuem conhecimento superficial sobre a história do Vogue, motivações intrínsecas semelhantes aos norteamericanos que originaram a cultura, mas também motivação extrínseca, que não foi encontrada nos primeiros praticantes da modalidade.

FREITAS, H. et al. O método de pesquisa survey. Revista de Administração, São Paulo v.35, n. 3, p.105-112, julho/setembro de 2000.

JACKSON, J. D. The Social World of Voguing. Journal for the Anthropological Study of Human Movement. 2002.

RYAN, R. M.; DECI, E. L. Intrinsic and Extrinsic Motivations: Classic Definitions and New Directions. Contemporary Educational Psychology 25, 54-67. 2000 . 